\title{
Biology of Zygogramma bicolorata (Pallister) on Parthenium hysterophorus (Linnaeus) at Different Temperatures in Odisha
}

\author{
Amrit Mohapatra, Subhalaxmi Roy ${ }^{*}$ and B. K. Mishra \\ Institute of Agricultural Sciences, Department of Entomology, SOADU, \\ Bhubaneswar, Odisha, India \\ *Corresponding author
}

\begin{abstract}
A B S T R A C T
Keywords

Zygogramma bicolorata,

Parthenium hysterophorus, Biology,

Temperature

Article Info

Accepted:

07 January 2021

Available Online:

10 February 2021

The studies on the Biology of Zygogramma bicolorata on Parthenium hysterophorus was taken up in Department of Entomology, Institute of Agricultural Sciences, SOADU during 2019-20. It was observed that all the biological parameters like the duration of different stages, morphometric measurements of different life stages were highest at $30^{\circ} \mathrm{C}$ followed by $25^{\circ} \mathrm{C}$. But at $20^{\circ} \mathrm{C}$ and $35^{\circ} \mathrm{C}$, the parameters showed declining trends indicating that $25-30^{\circ} \mathrm{C}$ is the best for rearing of these predatory beetles in the laboratory. As evidenced from the experiments, it was seen from the length of grubs increased from $1.31 \mathrm{~mm}$ to $5.75 \mathrm{~mm}$ at $20^{\circ} \mathrm{C}$ whereas, it was 1.58 to 5.81 and 1.65 to $5.90 \mathrm{~mm}$ at 25 and $30^{\circ} \mathrm{C}$ respectively. But at $35^{\circ} \mathrm{C}$ it declined to 1.61 to $5.86 \mathrm{~mm}$. Similarly, all stages like the second, third and fourth instars as well as the male and females also less at 20 and $35^{\circ} \mathrm{C}$ whereas, it was higher at 25 and $30^{\circ} \mathrm{C}$.

\section{Introduction}

Parthenium hysterophorus Linn. (Asteraceae) is one of the most noxious weeds in India which is mostly found in barrened lands, borders of roads, lakes, ponds, drains, rails, banks of rivers. It is also a great problem of cultivated lands. It is commonly known as "Congress grass", "Chatak chandani", "Gajar gavat" and "Pandharfuli". It is a native of West Indies, Central and North America but was introduced into India along with food grain imported under PL -480 or "Food for Peace" scheme, which is a food

support programme of the US government and spread terrifyingly to almost all the states of India and established as a troublesome weed. Efforts have been made to cope the weed employing different methods such as mechanical, competitive replacement (allelopathy), chemical, and biological control methods (Gupta et al., 2010 and Kaur et al., 2014). At present parthenium has invaded about 35 million hectares in India. It is a nuisance on road sides, railway tracks, barren lands, waste lands, industrial areas, on the sides of open drainage system and irrigation canals, besides invading agricultural crops,
\end{abstract}


orchards and forest area. It mainly spreads through seeds. Single plant can produce about 5,000 to 25,000 seeds. Seeds are very small and light in weight so easily carried or transported by wind, water or through various human activities. In general, parthenium is a poisonous, pernicious, problematic, allergic and aggressive weed posing a serious threat to human being and livestock. Besides ill effects, it also causes several other problems like blockage of common pathways and reduces the aesthetic values of parks, gardens and residential colonies (Anonymous, 2010). The Mexican beetle, Zygogramma bicolorata Pallister (Coleoptera: Chrysomelidae) an effective bio-control agent of P. hysterophorus, was introduced in 1983 from Mexico to Bangalore. Both adults and larvae of $Z$. bicolorata can feed on leaves, terminal buds and leaf blades of parthenium. Since the first release in the field in 1984 at Bangalore, the beetles became established in most part of the South India and many parts of the Central and North India. In many states of India, beetles have been established and contributing to controlled parthenium very effectively and economically without causing hazards to the existing ecosystem (Anonymous, 2010).

\section{Materials and Methods}

Studies were conducted at Laboratory, Department of Agricultural Entomology, Institute of Agricultural Sciences, SOA Deemed to be University, Bhubaneswar with ten replications.

\section{Maintenance of stock culture of Z. bicolorata}

The adults of $Z$. bicolorata were collected from the fields. The Beetles were confined in transparent glass jar $(10 \mathrm{~cm}$ in height and 5 $\mathrm{cm}$ in diameter) and provided with parthenium branches with fresh leaves as food. The leaves were provided in the form of bouquets, with their cut ends covered with moist cotton swab to prevent the leaves from quick drying. The jars were covered with white muslin cloth and secured with rubber band. Food was changed daily. Z. bicolorata laid eggs on the under surface of leaves and under surface of cotton cloth. They were removed with the help of fine camel hair brush and scissor and placed in separate petridishes $(110 \mathrm{~mm})$ for further rearing. Care was taken to avoid mechanical injury during transfer of eggs. On hatching, larvae were also provided with sufficient leaves of parthenium as a food. Continuous supply of parthenium leaves was made for maintaining laboratory culture of $Z$. bicolorata. Full grown larvae were provided with moistened soil for pupation.

The beetles were reared for two generations in laboratory. Tender leaves of parthenium was changed daily and the third generation was used for studying the biology of the Zygogramma beetle in a BOD incubator. The mating pair was kept in the Petri plates of dimension $(1.5 \times 8 \mathrm{~cm})$. The adults were fed with mixture of tender leaves, old leaves, and inflorescence. Rest of the beetles were kept in a transparent plastic jar $(10 \mathrm{~cm}$ in height and 5 $\mathrm{cm}$ in diameter). One hundred laid eggs were removed with the help of fine camel hair brush and placed separately in petridishes (1.5 $\mathrm{cm}$ depth $\mathrm{x} 8 \mathrm{~cm}$ height). Proper attention was given for any mechanical injury during transfer of eggs. On hatching, early instar larvae were fed with tender leaves of parthenium as a food. Continuous supply of parthenium leaves was given to the larvae for preserving the culture $Z$. bicolorata. The larvae molted three times and the instars were judged with the help of exuvia of the larva that was observed daily in the morning hours. Along with recording the incubation period and period between the instars, the measurements of the eggs and the larvae were studied under ocular and stage micrometres. 
Upon attending pre-pupal stage, the beetles were transferred to glass jars containing a $5 \mathrm{~cm}$ layer of loose sandy soil for allowing pupation. They entered inside soil and pupated. The pupae were dug out for their morphometric and other observations. Morphometric observation was done for length, breadth and head width of the first to fourth instars larva, pupa and adults (male and female). The size of adult male is smaller than the adult female. Many a times size is taken as a parameter to distinguish male and female adult. The data on size was collected and statistically analysed.

\section{Biology of Zygogramma bicolorata on Parthenium hysterophorus}

The work on biology of Zygogramma bicolorata on Parthenium hysterophorus was executed in laboratory during October 2019 to July 2020 at $\left(25 \pm 10^{\circ} \mathrm{C}\right)$ and relative humidity $(70 \pm 5 \%)$. One hundred eggs, ten each in a petridish, were used to study the morphometric and biology aspect of the Zygogramma bicolorata, thus maintaining ten replications. Incubation period was calculated as the time between the dates of laying eggs and date of egg hatching. The specific colour and the shape of the egg were observed. Keeping in view the objective of study, the number and duration of larval instars was necessary to be taken into note. The hatched larvae from the eggs from each petridish were keenly observed for knowing the larval instars and duration of each larval instar. The morphometric measurement of the eggs and the larva is done using microscope under ocular and stage micrometres. Duration of first instar was calculated by noting the period between date of hatching and date of first moulting. Duration of second instar is calculated by noting the period between date of first moulting to date of second moulting. Duration of third instar was calculated by noting the period between date of second moulting and the date of third moulting. Duration of fourth instar was calculated by noting the period between date of third moulting to date of fourth moulting. Pre-pupal period stage is characterized by lack of appetite, the full-grown larvae rest without feeding for a few hours to one day on the under surface of leaves before burrowing into the soil for pupation. The period of pupal stage is noted from the time the larva forms pupa, enters the soil to adult emergence. Preoviposition period was estimated by the duration between adult female emergence to becoming capable of laying eggs, and the interval between the inception of egg laying to termination of egg laying is estimated as oviposition period, and interval between termination of egg laying to the mortality of female was considered as post-oviposition period. For the purpose of determining the pre-oviposition, oviposition and postoviposition period the mating pair were separated, forty numbered and kept in petridishes ( $5 \mathrm{~cm}$ in diameter). The dimension viz. length and breadth of pupa was estimated with the help of a scale. Colour, shape, and size of the adult was also noted with the help of a scale. The adult mating pairs were regularly fed with fresh tender parthenium leaves, so that the female adult can realize maximum fecundity. The eggs laid by female in each plastic container was separated and counted every morning (9:00 am-10.00 am), then the mating pair were again transferred to their original plastic container after cleaning the debris to commence mating/oviposition. The total number of eggs laid in entire life span of adult female was called fecundity. Along with estimating and maintaining all the observation, the longevity of the male and female adults was also observed and noted, from date of emergence to date of death of the beetle. Total life cycle was estimated from the period between the date of egg laying to the death of the beetles. In order to estimate the sex-ratio (Male: Female) under controlled 
laboratory environment, the number of male and females that emerged were counted.

In order to determine the pre oviposition period, the newly emerged 10 pairs adults of Z. bicolorata were kept separately in plastic container $(10 \mathrm{~cm}$ in height and $5 \mathrm{~cm}$ in diameter). A bouquet of parthenium leaves was provided as food. The period between the emergence of adult female and commencement of egg laying was recorded as the pre-oviposition period. Period between commencement the egg laying and ceasing of the egg laying by individual female was recorded as oviposition period and period between ceasing of egg laying to death of female was considered as post-oviposition period. Eggs laid by female were collected and counted daily in the morning (8:00 to 10:00 am). The total number of eggs laid during the life span of the adult female was considered as its fecundity. Longevity of male and female beetles was calculated separately from the date of emergence to death of adults. Total life cycle was considered as the period between the dates of egg laying to the death of adults.

The morphometric observation of each stage, i.e., egg, larval instars, pupa and adult (Male and female) was taken using ocular micrometre under a stereo binocular microscope.

\section{Results and Discussion}

\section{Studies on the biology of Zygogramma bicolorata under laboratory conditions}

The biology of Z. bicolorata was studied under laboratory condition in the department of Entomology, Institute of Agricultural Sciences, SOADU, during 2019-20 under different temperature regimes i.e., at $25^{\circ} \mathrm{C}$, $30^{\circ} \mathrm{C}, 35^{\circ} \mathrm{C}$ and the results are depicted below.

\section{Duration of different life stages of various temperature}

The life history parameter of $Z$. bicolorata at $25^{\circ} \mathrm{C}$ is presented in Table 1 . The incubation period varied between 4-5 (4.56 \pm 1.04$)$ days, and the hatching was in the range of 79-80 $(79.75 \pm 0.49) \%$. Duration of different larval instar, indicated that the first instar continued for $4-6(4.48 \pm 0.94)$ day, whereas, the second, third and fourth instars ranged between 2-4

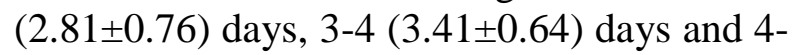
$6(4.61 \pm 0.75)$ days respectively. The total larval of duration was found to be in the range of 13-20 (15.83 \pm 3.51$)$ days. The prepupal, pupal period was observed to be in the range of 2-3 (1.66 \pm 0.59$)$ days and 9-11 (9.97 \pm 0.84$)$ days respectively. The beetles passed through a preoviposition period of $8-10(8.55 \pm 0.68)$ days before laying eggs. The egg laying period i.e. the oviposition period was recorded to be 44-47 (45.35 \pm 1.52$)$ days. The post oviposition period was 17-20 $(18.37 \pm 0.83) \quad$ days. There was 71-75 $(72.09 \pm 2.97) \%$ adult emergence with a sex ratio of 1.21:1.39. Males lived for 33-45 (35.01 \pm 8.06$)$ days, whereas the females lived for 46-56 (48.75 \pm 7.41$)$ days. The total life cycle form eggs to adult took 61-71 $(62.43 \pm 7.33)$ days in case of males, whereas, the females completed egg to adult period in 69-79 (70.33 \pm 8.27$)$ days. The fecundity at 250C was from 621-690 (667.75 \pm 12.32$)$. Bhoopathi et al (2006) observed that $25^{\circ} \mathrm{C}$ is the optimum for the growth and development of Z. bicolorata and our findings were in agreement to their observation. Siddhapara $e t$ al., (2012); Mehta and Raghuraman (2019) had also similar observations while studying the biology of $Z$. bicolorata.

Perusal of data in Table 1 indicated that, at $30^{\circ} \mathrm{C}$, the incubation period lasted for $4-6$ (4.64 \pm 1.07$)$ days, and the hatching percentage of eggs ranged between 79-81 (79.84 \pm 0.55$) \%$. 
Table.1 Parameter of Developmental stages of Z. bicolorata on P. hysterophorus under laboratory conditions at different temperatures $\left(25^{\circ} \mathrm{C}, 30^{\circ} \mathrm{C}\right.$ and $\left.35^{\circ} \mathrm{C}\right)$

\begin{tabular}{|c|c|c|c|c|c|c|}
\hline \multirow[b]{2}{*}{ Particulars } & \multicolumn{2}{|c|}{$25^{\circ} \mathrm{C}$} & \multicolumn{2}{|c|}{$30^{0} \mathrm{C}$} & \multicolumn{2}{|c|}{$35^{\circ} \mathrm{C}$} \\
\hline & Range & Mean \pm S.D. & Range & Mean \pm S.D. & Range & Mean \pm S.D. \\
\hline Incubation period (Days) & 4-5 & $4.56 \pm 1.04$ & $4-6$ & $4.64 \pm 1.07$ & $4-6$ & $4.59 \pm 1.06$ \\
\hline Hatching percentage $(\%)$ & $79-80$ & $79.75 \pm 0.49$ & $79-81$ & $79.84 \pm 0.55$ & $79-81$ & $79.79 \pm 0.53$ \\
\hline \multicolumn{7}{|l|}{ Larval period (Days) } \\
\hline $1^{\text {st }}$ instar & $4-6$ & $4.48 \pm 0.94$ & $4-6$ & $4.55 \pm 0.99$ & $4-6$ & $4.51 \pm 0.97$ \\
\hline $2^{\text {nd }}$ instar & $2-4$ & $2.81 \pm 0.76$ & $2-4$ & $2.91 \pm 0.84$ & $2-4$ & $2.87 \pm 0.81$ \\
\hline $3^{\text {rd }}$ instar & $3-4$ & $3.41 \pm 0.64$ & $3-5$ & $3.50 \pm 0.75$ & $3-5$ & $3.47 \pm 0.71$ \\
\hline $4^{\text {th }}$ instar & $4-6$ & $4.61 \pm 0.75$ & $3-6$ & $4.70 \pm 0.82$ & $3-6$ & $4.67 \pm 0.79$ \\
\hline Total larval period (Days) & $13-20$ & $15.83+3.51$ & $13-20$ & $15.94+3.56$ & $13-20$ & $15.88+3.51$ \\
\hline Pre-pupal (Days) & $2-3$ & $1.66 \pm 0.59$ & $1-3$ & $1.73 \pm 0.65$ & $1-3$ & $1.69 \pm 0.61$ \\
\hline Pupal period (Days) & $9-11$ & $9.97 \pm 0.84$ & $9-12$ & $10.14 \pm 0.92$ & $9-12$ & $10.02 \pm 0.86$ \\
\hline Pre-Oviposition period (Days) & $8-10$ & $8.55 \pm 0.68$ & $7-10$ & $8.64 \pm 0.75$ & $7-10$ & $8.59 \pm 0.72$ \\
\hline Oviposition period (Days) & $44-47$ & $45.35 \pm 1.52$ & $44-48$ & $45.52 \pm 1.61$ & $44-48$ & $45.48 \pm 1.58$ \\
\hline Post-oviposition period (Days) & $17-20$ & $18.37 \pm 0.83$ & $17-20$ & $18.44 \pm 0.92$ & $17-20$ & $18.40 \pm 0.89$ \\
\hline Adult emergence $(\%)$ & $71-75$ & $72.09 \pm 2.97$ & $71-76$ & $72.21 \pm 3.04$ & $71-76$ & $72.15 \pm 3.04$ \\
\hline Sex-ratio (Male : Female) & $1.58-1.62$ & $1.21: 1.39$ & $1.58-1.62$ & $1.29: 1.45$ & $1.58-1.62$ & $1.24: 1.42$ \\
\hline \multicolumn{7}{|l|}{ Adult longevity (Days) } \\
\hline Male & $33-45$ & $35.01 \pm 8.06$ & $33-45$ & $35.05 \pm 8.11$ & $33-45$ & $35.03 \pm 8.09$ \\
\hline Female & $46-56$ & $48.75 \pm 7.41$ & $46-57$ & $48.83 \pm 7.49$ & $46-57$ & $48.79 \pm 7.44$ \\
\hline \multicolumn{7}{|l|}{ Total life cycle (Days) } \\
\hline Male & $61-71$ & $62.43 \pm 7.33$ & $61-71$ & $62.53 \pm 7.42$ & $61-71$ & $62.48 \pm 7.39$ \\
\hline Female & $69-79$ & $70.33 \pm 8.27$ & $69-80$ & $70.48 \pm 8.36$ & $69-80$ & $70.41 \pm 8.31$ \\
\hline Fecundity & $621-690$ & $667.75 \pm 12.32$ & $671-690$ & $672.74 \pm 12.56$ & $671-690$ & $670.69 \pm 12.44$ \\
\hline
\end{tabular}


Table.2 Morphometric particulars of different life stages of Zygogramma bicolorata under laboratory conditions. $\left(25^{0} \mathrm{C}\right)$

\begin{tabular}{|c|c|c|c|c|c|c|}
\hline \multirow[t]{2}{*}{ Stage } & \multicolumn{2}{|c|}{ Length (mm) } & \multicolumn{2}{|c|}{ Breadth $(\mathrm{mm})$} & \multicolumn{2}{|c|}{ Head width (mm) } \\
\hline & Range & Mean \pm SD & Range & Mean \pm SD & Range & Mean \pm SD \\
\hline Egg & $1.0-1.5$ & $1.36 \pm 0.14$ & $0.5-0.6$ & $0.55 \pm 0.02$ & & \\
\hline \multicolumn{7}{|c|}{ Larval stages } \\
\hline $1^{\text {st }}$ instar & $1-3$ & $1.58 \pm 0.10$ & $6-7$ & $0.68 \pm 0.18$ & $0.5-0.6$ & $0.58 \pm 0.01$ \\
\hline $2^{\text {nd }}$ instar & $2-3$ & $2.61 \pm 0.20$ & $7-8$ & $0.79 \pm 0.10$ & $0.7-0.8$ & $0.72 \pm 0.52$ \\
\hline $3^{\text {rd }}$ instar & $4-5$ & $4.57 \pm 0.34$ & $2-3$ & $2.29 \pm 0.11$ & $09-1.2$ & $1.10 \pm 0.03$ \\
\hline $4^{\text {th }}$ instar & $5-7$ & $5.81 \pm 0.41$ & $3-4$ & $3.51 \pm 0.52$ & $1.4-1.5$ & $1.49 \pm 0.05$ \\
\hline Pupa & $6-7$ & $6.26 \pm 0.15$ & $3-4$ & $3.41 \pm 0.06$ & & \\
\hline \multicolumn{7}{|l|}{ Adult } \\
\hline Male & $6-7$ & $6.11 \pm 0.18$ & $3-4$ & $3.21 \pm 0.15$ & $0.9-1.2$ & $0.77 \pm 0.37$ \\
\hline Female & $6-8$ & $6.26 \pm 0.41$ & $3-4$ & $3.29 \pm 0.34$ & $0.9-1.3$ & $0.79 \pm 0.32$ \\
\hline
\end{tabular}

Table.3 Morphometric particulars of different life stages of Zygogramma bicolorata under laboratory conditions. $\left(30^{\circ} \mathrm{C}\right)$

\begin{tabular}{|c|c|c|c|c|c|c|}
\hline \multirow{2}{*}{ Stage } & \multicolumn{2}{|c|}{ Length (mm) } & \multicolumn{2}{|c|}{ Breadth (mm) } & \multicolumn{2}{|c|}{ Head width (mm) } \\
\hline & Range & Mean \pm SD & Range & Mean \pm SD & Range & Mean \pm SD \\
\hline Egg & $1.0-1.6$ & $1.41 \pm 0.15$ & $0.51-0.03$ & $0.58 \pm 0.03$ & & \\
\hline \multicolumn{7}{|l|}{ Larval stages } \\
\hline $1^{\text {st }}$ instar & $1-3$ & $1.60 \pm 0.11$ & $0.7-1.0$ & $0.71 \pm 0.20$ & $0.5-0.6$ & $0.63 \pm 0.03$ \\
\hline $2^{\text {nd }}$ instar & $2-3$ & $2.60 \pm 0.21$ & $0.80-1.0$ & $0.83 \pm 0.12$ & $0.7-0.8$ & $0.77 \pm 0.56$ \\
\hline $3^{\text {rd }}$ instar & $4-5$ & $4.60 \pm 0.39$ & $2-3$ & $2.33 \pm 0.14$ & $09-1.2$ & $1.18 \pm 0.06$ \\
\hline $4^{\text {th }}$ instar & $5-7$ & $5.87 \pm 0.48$ & $3-5$ & $3.57 \pm 0.55$ & $1.4-1.5$ & $1.55 \pm 0.10$ \\
\hline Pupa & $6-7$ & $6.29 \pm 0.17$ & $3-4$ & $3.47 \pm 0.10$ & & \\
\hline \multicolumn{7}{|l|}{ Adult } \\
\hline Male & $6-7$ & $6.17 \pm 0.20$ & $3-4$ & $3.18 \pm 0.19$ & $0.9-1.0$ & $0.71 \pm 0.28$ \\
\hline Female & $6-8$ & $6.30 \pm 0.45$ & $3-4$ & $3.34 \pm 0.37$ & $0.9-1.2$ & $0.28 \pm 0.42$ \\
\hline
\end{tabular}

Table.4 Morphometric particulars of different life stages of Zygogramma bicolorata under laboratory conditions. $\left(35^{\circ} \mathrm{C}\right)$

\begin{tabular}{|c|c|c|c|c|c|c|}
\hline Stage & \multicolumn{2}{|c|}{ Length $(\mathbf{m m})$} & \multicolumn{2}{c|}{ Breadth $(\mathbf{m m})$} & \multicolumn{2}{c|}{ Head width $(\mathbf{m m})$} \\
\hline & Range & Mean \pm SD & Range & Mean \pm SD & Range & Mean \pm SD \\
\hline Egg & $1.0-1.6$ & $1.39 \pm 0.14$ & $0.51-0.6$ & $0.56 \pm 0.04$ & & \\
\hline Larval stages & \multicolumn{7}{|c|}{} \\
\hline $\mathbf{1}^{\text {st }}$ instar & $1-3$ & $1.61 \pm 0.13$ & $0.7-1.0$ & $0.70 \pm 0.18$ & $0.5-0.6$ & $0.60 \pm 0.01$ \\
\hline $\mathbf{2}^{\text {nd }}$ instar & $2-3$ & $2.60 \pm 0.22$ & $0.80-1.0$ & $0.81 \pm 0.10$ & $0.7-0.8$ & $0.75 \pm 0.52$ \\
\hline $\mathbf{3}^{\text {rd }}$ instar & $4-5$ & $4.59 \pm 0.36$ & $2-3$ & $2.31 \pm 0.12$ & $09-1.2$ & $1.15 \pm 0.04$ \\
\hline $\mathbf{4}^{\text {th }}$ instar & $5-7$ & $5.85 \pm 0.44$ & $3-5$ & $3.54 \pm 0.51$ & $1.4-1.5$ & $1.53 \pm 0.07$ \\
\hline Pupa & $6-7$ & $6.29 \pm 0.17$ & $3-4$ & $3.47 \pm 0.10$ & & \\
\hline Adult & \multicolumn{7}{|c|}{} & & & \\
\hline Male & $6-7$ & $6.15 \pm 0.18$ & $3-4$ & $3.20 \pm 0.18$ & $0.9-1.0$ & $0.69 \pm 0.22$ \\
\hline Female & $6-8$ & $6.27 \pm 0.43$ & $3-4$ & $3.30 \pm 0.33$ & $0.9-1.0$ & $0.72 \pm 0.29$ \\
\hline
\end{tabular}


At the temperature of $300 \mathrm{C}$, the duration of different larval instars, 4-6 (4.55 \pm 0.99$), 2-4$ $(2.91 \pm 0.84), \quad 3-5 \quad(3.50 \pm 0.75)$ and 4-6 (4.70 \pm 0.82$)$ days for the $1 \mathrm{st}, 2 \mathrm{nd}, 3 \mathrm{rd}$ and 4 th instars respectively. The total larval of duration was 13-20(15.94 \pm 3.56$)$ days. The prepupal and pupal periods were in the range of $1-3 \quad(1.73 \pm 0.65)$ days and 9-12 $(10.14 \pm 0.92)$ days respectively. There was a preoviposition period of $8-10(8.64 \pm 0.75)$ days before laying eggs. Egg laying continued for a period of $44-48(45.52 \pm 1.61)$ days. The post oviposition period was 17-20 (18.44 \pm 0.92$)$ days. Adult emergence was 71$76(72.21 \pm 3.03) \%$ and the sex ratio was 1.29:1.45. Males lived for 33-45 (35.05 \pm 8.11$)$ and the females lived for 46-57 (48.83 \pm 7.49$)$ days respectively. Time taking to complete eggs to adult stages took 61-71 (62.53 57.42$)$ days in case of males and 69-80 (70.48 \pm 8.36$)$ days in case of females. A female laid 671$690(672.74 \pm 12.56)$ eggs during its life cycle at $30^{\circ} \mathrm{C}$. It was generally observed that, with the increase in ambient temperature, the duration of different life stages are increasing. Similar observations have been recorded by Gautam (2006) and Pawar et al., (2013).

Duration of different life stages of $Z$. bicolorata at $35^{\circ} \mathrm{C}$ is presented in Table 1.

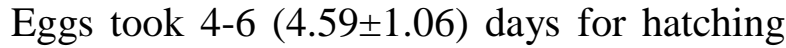
and 79-81 (79.79 \pm 0.53$) \%$ eggs hatched. The larval stages took for 4-6 (4.51 \pm 0.97$), 2-4$ $(2.87 \pm 0.81), \quad 3-5 \quad(3.47 \pm 0.71)$ and $4-6$ (4.67 \pm 0.79$)$ days for first, second, third and fourth instars respectively. The total larval period was found to be in the range of 13-20 (15.88 \pm 3.51$)$. The prepupal, pupal period was observed to be in the range of 1-3 $(1.69 \pm 0.61)$ days and 9-12 (10.02 \pm 0.86$)$ days respectively. The pre-oviposition period was7-10 $(8.44 \pm 0.72)$ and the oviposition period was recorded in the range of 44-48 (45.48 \pm 1.58$)$ days. The post oviposition period was found

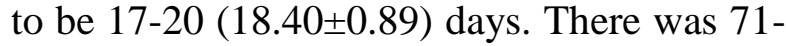
$76(72.15 \pm 3.04) \%$ adult emergence with a sex ratio of 1.24:1.42. Males lived for 33-45 $(35.03 \pm 8.09)$ days, whereas, the females lived for 46-57 (48.79 \pm 8.09$)$ days respectively. The total life cycle form eggs to adult took 61-71 $(62.48 \pm 7.39)$ days in case of males. On the other hand, the female took $69-80$ (70.41 \pm 8.31 ) days for completing the total life cycle. The fecundity at $35^{\circ} \mathrm{C}$ varied from $671-$ $690(670.69 \pm 12.44)$. It was found that the higher temperature of $35^{\circ} \mathrm{C}$ was detrimental for the growth as indicated by the decreasing time taken for the completion of different life stages. Bhoopathi et al., (2006) had also observed similar trend in the biology of $Z$. bicolorata.

\section{Growth and development of Z $\mathrm{Z}$. bicolorata at different temperature}

The length and breadth of eggs at $25^{\circ} \mathrm{C}$ measured 1.0-1.5 (1.36 \pm 0.14$)$ days and 0.5$0.6(0.55 \pm 0.02) \mathrm{mm}$ respectively in table 2 . The first instar larvae were 1-3 (1.58 \pm 0.10$)$ $\mathrm{mm}$ in length and 0.6-0.7 (0.68 \pm 0.18$) \mathrm{mm}$ in breadth respectively. The head capsule of first instar was $0.5-0.6(0.58 \pm 0.01) \mathrm{mm}$ wide. The second instar larvae measured 2.0-3.0 $(2.61 \pm 0.20) \mathrm{mm}$ in length and $0.7-0.8$ $(0.79 \pm 0.10) \mathrm{mm}$ respectively with a head capsule of $0.7-0.8(0.72 \pm 0.52) \mathrm{mm}$. The third instar larvae were to $4.0-5.0(4.57 \pm 0.34) \mathrm{mm}$ in length and 2.0-3.0 (2.29 \pm 0.11$) \mathrm{mm}$ in breadth and their head capsule width was 0.9$1.2(1.10 \pm 0.03) \mathrm{mm}$. The fourth instar larvae measured 5.0-7.0 $(5.81 \pm 0.41) \mathrm{mm}$ in length and 3.0-4.0 (3.51 \pm 0.52$) \mathrm{mm}$ in width with head capsule width of 1.4-1.5 (1.49 \pm 0.05$)$ $\mathrm{mm}$. The pupae were 6-7 $(6.26 \pm 0.15) \mathrm{mm}$ long and 3.0-4.0 (3.38 \pm 0.05$) \mathrm{mm}$ wide. The males measured 6-7 $(6.11 \pm 0.18) \mathrm{mm}$ in length and 3.0-4.0 (3.21 \pm 0.15$) \mathrm{mm}$ in width. Males had a head capsule width of0.9$1.2(0.77 \pm 0.37) \mathrm{mm}$. The female were 6-8 (6.26 \pm 0.41$) \mathrm{mm}$ long and 3.0-4.0 (3.29 \pm 0.34$)$ $\mathrm{mm}$ wide. Female had possessed a capsule width of $0.9-1.3(0.79 \pm 0.32)$. 
Perusal of data in Table 3 revealed that, eggs

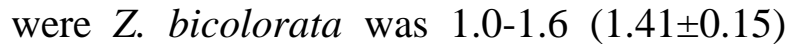
$\mathrm{mm}$ long and 0.51-0.03 (0.58 \pm 0.03$) \mathrm{mm}$ broad at $30^{\circ} \mathrm{C}$ respectively. The First instar larvae were $1.0-3.0(1.60 \pm 0.11) \mathrm{mm}$ in long and $0.7-1.0 \quad(0.71 \pm 0.20) \mathrm{mm}$ in wide respectively. The head capsule of first instar was $0.5-0.6(0.63 \pm 0.03) \mathrm{mm}$. The length and breadth of second instar larvae were 2.0-3.0 $(2.60 \pm 0.21) \mathrm{mm}$ and $0.7-0.8(0.77 \pm 0.56) \mathrm{mm}$ respectively with head capsule of $0.7-0.8$ $(0.77 \pm 0.56) \mathrm{mm}$. The third instar larvae were found to be 4.0-5.0 (4.60 \pm 0.39$) \mathrm{mm}$ in length and 2.0-3.0 $(2.33 \pm 0.14) \mathrm{mm}$ in breadth and showed the head capsule 0.9-1.2 (1.18 \pm 0.06$)$ $\mathrm{mm}$. The fourth instar larvae measured 5.0$7.0 \quad(5.87 \pm 0.48) \mathrm{mm}$ length and 3.0-5.0 $(3.57 \pm 0.55) \mathrm{mm}$ in breadth and their head capsule width was of 1.4-1.5 (1.55 \pm 0.10$) \mathrm{mm}$. The pupae were 6-7 $(6.29 \pm 0.17) \mathrm{mm}$ long and 3.0-4.0 (3.47 \pm 0.10$) \mathrm{mm}$ wide. Males were 6-7 $(6.17 \pm 0.20) \mathrm{mm}$ in length and 3.0-4.0 $(3.18 \pm 0.19) \mathrm{mm}$ in breadth. Males had a head capsule width of $0.9-1.0(0.71 \pm 0.28) \mathrm{mm}$. The female were $6-8(6.30 \pm 0.45) \mathrm{mm}$ long and $3.0-4.0(3.34 \pm 0.37) \mathrm{mm}$ wide. Female had possessed a had capsule width of 0.9-1.2 $(0.78 \pm 0.42)$. The eggs of $Z$. bicolorata were observed to be 1.0-1.6 (1.39 \pm 0.14$) \mathrm{mm}$ long and $0.51-0.06(0.56 \pm 0.04) \mathrm{mm}$ broad at $35^{\circ} \mathrm{C}$ (Table 4) respectively. The first instar larvae measured 1.0-3.0 (1.61 \pm 0.13$) \mathrm{mm}$ in length and $0.7-1.0 \quad(0.70 \pm 0.18) \mathrm{mm}$ in breadth respectively. The head capsule of 1 st instar was $0.5-0.6(0.60 \pm 0.01) \mathrm{mm}$. Length and breadth of second instar larvae were 2.0-3.0 $(2.60 \pm 0.22) \mathrm{mm}$ and $0.80-1.0(0.81 \pm 0.10) \mathrm{mm}$ respectively with a head capsule of $0.7-0.8$ $(0.75 \pm 0.52) \mathrm{mm}$ wide. The third instar larvae increased to 4.0-5.0 (4.59 \pm 0.36$) \mathrm{mm}$ in length and 2.0-3.0 (2.31 \pm 0.12$) \mathrm{mm}$ in breadth and

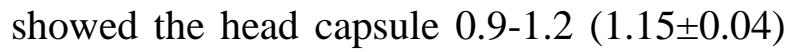
$\mathrm{mm}$. The fourth instar larvae were 5.0-7.0 $(5.85 \pm 0.44) \mathrm{mm}$ long and 3.0-5.0 (3.54 \pm 0.51$)$ $\mathrm{mm}$ in wide with head capsule width of 1.4$1.5(1.53 \pm 0.07) \mathrm{mm}$. The pupae were 6-7
$(6.29 \pm 0.17) \mathrm{mm}$ long and 3.0-4.0 (3.47 \pm 0.10$)$ $\mathrm{mm}$ wide. The males were 6-7 $(6.15 \pm 0.18)$ $\mathrm{mm}$ in length and 3.0-4.0 (3.20 \pm 0.18$) \mathrm{mm}$ in width. Males had possessed a head capsule width of $0.9-1.0(0.69 \pm 0.22) \mathrm{mm}$. The female were 6-8 (6.27 40.43$) \mathrm{mm}$ long and 3.0-4.0 (3.30 \pm 0.33$) \mathrm{mm}$ wide. Female had possessed a head capsule width of $0.9-1.1(0.72 \pm 0.29)$ mm.

\section{References}

Anonymous, 2010. Biological Control of Parthenium. Directorate of Weed Science Research, Jabalpur, Madhya Pradesh, India, p. 1-4.

Bhoopathi R. 2006. Studies on Zygogramma bicolorata pallister - a potential biocontrol agent of Parthenium hysterophorus Linnaeus. $\mathrm{PhD}$ thesis submitted to IARI, New Delhi, India, 28-29.

Gautam, R.D, Md. Aslam Khan and A.K. Garg. 2006. Ecological adaptability and variations among population of Mexican beetle, Zygogramma bicolorata pallister (Chrysomelidae: Coleoptera). Journal of Entomological Research, 30: 21-23.

Gupta RK, Gupta S, Bali K, Srivastava K. 2010. Enhancing bio-suppression of Parthenium hysterophorus L.: Diapause in Zygogramma bicolorata Pallister and its manipulation through insulin-like peptides (ILPs). Journal of Asia-Pacific Entomology.

Kaur M, Aggarwal NK, Kumar V and Dhiman R. 2014. "Effects and Management of Parthenium hysterophorus: A Weed of Global Significance", International Scholarly Research Notices. 368647-368658

Mehta MC and Raghuraman M. 2019. Study on biology and morphometric aspects of Zygogramma bicolorata Pallister (Coleoptera: Chrysomelidae) on 
parthenium in Varanasi region, India. Journal of Pharmacognosy and Phytochemistry, 8(2): 1694-1699.

Pawar SR, Sangle PM, Korat DM. 2015. Biology and morphometric studies of Mexican beetle, Zygogramma bicolorata Pallister on Parthenium, 291292.
Siddhapara MR, Patel MB and Patel HV. 2012. Biology of Zygogramma bicolorata Pallister (Coleoptera: Chrysomelidae) and Their Feeding Potential on Parthenium and Sunflower. Madras Agricultural Journal, 99. 1012. 841-844.

\section{How to cite this article:}

Amrit Mohapatra, Subhalaxmi Roy and Mishra, B. K. 2021. Biology of Zygogramma bicolorata (Pallister) on Parthenium hysterophorus (Linnaeus) at Different Temperatures in Odisha. Int.J.Curr.Microbiol.App.Sci. 10(02): 515-523. doi: https://doi.org/10.20546/ijcmas.2021.1002.060 